\title{
Effects of Triton-X-100 upon the mobility of esterases and alkaline phosphatases in disc electrophoresis
}

\author{
H. B. COUTINHO, ${ }^{1}$ E. KATChBURIAn, ${ }^{2}$ AND A. G. E. PEARSE \\ From the Postgraduate Medical School, London
}

SYNOPSIS Homogenates of the mid gut and digestive glands of Rhynchosciara angelae were prepared in $40 \%$ sucrose, with and without $0.5 \%$ Triton-X-100. These were subjected to disc electrophoresis and zymograms for esterases and alkaline phosphatase were prepared. In both groups the effect of Triton-X-100 was to increase the electrophoretic mobility of the enzymes concerned.

When a tissue homogenate is submitted to gel electrophoresis part of the enzyme activity remains at the origin, or close to it, indicating that some fractions are insoluble and consequently unable to migrate. According to Eränko, Härkönen, Kokko, and Räisänen (1964) the esterases can be divided into soluble (lyo-esterase) and poorly soluble (desmoesterase) fractions. The zymogram method is of particular value for the study of lyo-esterases, while the desmo-esterases are mainly observed by histochemical methods (Eränkö, 1964).

In the course of an investigation on the variation of the zymograms of the Rhynchosciara angelae (Diptera, Sciaridae) during larval development, we noticed that both alkaline phosphatase and some esterases failed to move through the small-pore gel, and even more notably to penetrate the large-pore gel, when disc electrophoresis was used (Davis, 1964). Among the compounds used to release enzymes bound to cell structures Triton-X-100 was reported to be effective for 'liberating' lysosomal enzymes (Dé Duve, 1959). One effect of the Triton-X-100 that was observed by Barka (1961), using rat liver for the chromatographic separation of acid phosphatases, and by Allen and Gockerman (1964), in the mitochondrial-lysosomal fraction of rat liver after disc electrophoresis, was the ability to render enzymes soluble.

In order to ascertain whether similar effects could be obtained in the case of the esterases and alkaline phosphatase of the mid gut and digestive glands of Rhynchosciara angelae, homogenates in $40 \%$ sucrose were prepared. Triton-X-100 to a final concentration of $0.5 \%$ was added to an aliquot of the homogenates. For non-specific esterase $a$-naphthyl-

${ }^{1}$ Visiting colleague, Postgraduate Medical School, sponsored by the British Council.

'Research fellow of the Coordenacao do Aperfeicoamento de Pessoal de Nivel Superior, Brazil.

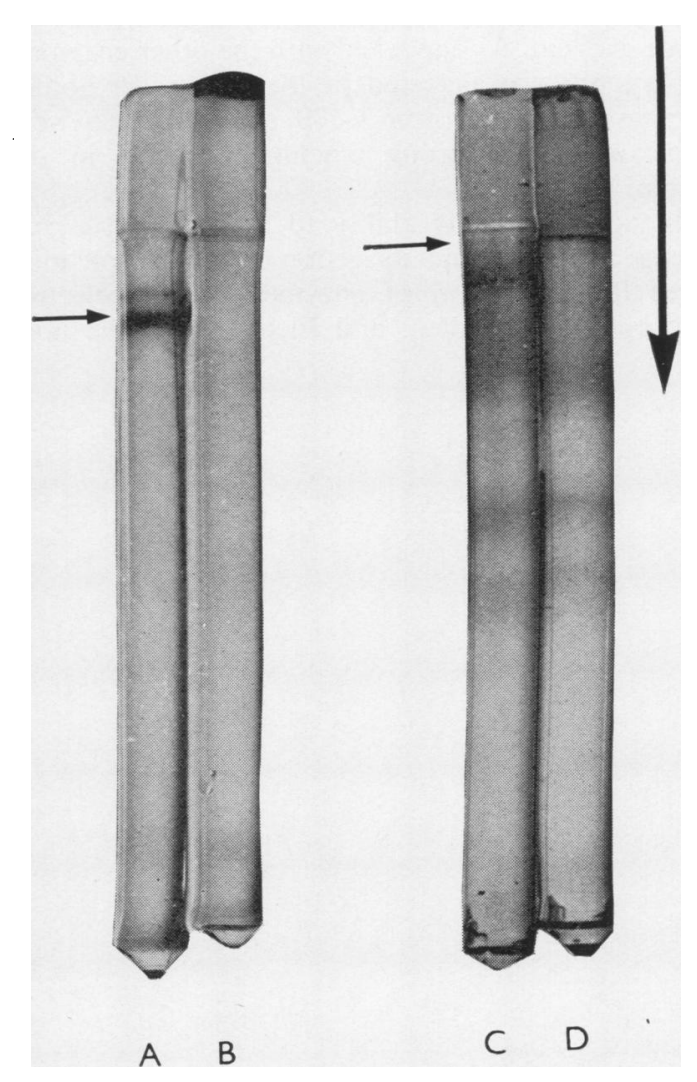

FIG. 1. Acrylamide gel columns stained for:

A Alkaline phosphatase after treatment by Triton$X-100$.

B Alkaline phosphatase without treatment by Triton$X-100$.

C Esterases after treatment by Triton-X-100.

D Esterases without treatment by Triton-X-100. 
butyrate was used as substrate and the diazonium salt Fast blue RR (C.I. 37155) as coupler. For alkaline phosphatase sodium- $\alpha$-naphthyl-phosphate was used as substrate and Fast red TR (C.I. 37085) as coupler according to directions given by Pearse (1960).

In homogenates lacking Triton-X-100 no bands of alkaline phosphatase were observed in the gel column; only a very strong and sharp staining was observed in the origin on the large-pore gel. In contrast the homogenates containing Triton-X-100 showed two bands of activity on the small-pore gel and no reaction persisted in the origin.

A rather complex zymogram pattern of the esterases of the mid gut and digestive glands was observed in homogenates containing Triton-X-100 (Fig. 1). In addition to the fact that more bands were present we noted an irregular and rough outline in some of them. As happened with the other enzymes, no activity was detected in the origin. In homogenates without Triton-X-100 several bands were observed but a strong reaction persisted in the origin.

In addition to its ability to render soluble and release enzymes, and its action in incubation mixtures for separation of enzymes by disc electrophoresis (Allen, Allen, and Licht, 1965), the non- ionic detergent Triton-X-100 has considerable effects at the cytochemical level when used in incubating media for enzymes (Katchburian, 1965). It is also of considerable value for improving the electrophoretic mobility of desmo-esterases and alkaline phosphatases.

We are grateful to Dr. F. S. Lara who kindly supplied कै the larvae and to Professor R. L. Hunter for providing the $\alpha$-naphthylbutyrate, and to Dr. F. W. D. Rost for the photographs.

The apparatus for electrophoresis was provided by a grant from the Central Research Fund of the University of London.

\section{REFERENCES}

Allen, J. M., and Gockerman, J. (1964). Ann. N.Y. Acad. Sci., 121, 616.

Allen, S. L., Allen, J. M., and Licht, B. M. (1965). J. Histochem. Cytochem., 13, 434.

Barka, T. (1961). Ibid., 9, 564.

Davis, B. J. (1964). Ann. N.Y. Acad. Sci., 121, 404.

Dé Duve, C. (1959). In Subcellular Particles, edited by T. Hayashi, p. 128. Ronald Press, New York.

Eränkö, O. (1964). 2nd int. Congr. Histo- and Cytochemistry, p. 115. Springer-Verlag, Berlin.

—, Härkönen, M., Kokko, A., and Räisänen, L. (1964). J. Histochem. Cytochem., 12, 570.

Katchburian, E. (1965). Unpublished.

Pearse, A. G. E. (1960). Histochemistry, Theoretical and Applied, 2nd ed. Churchill, London. 